\title{
Culture Creative Design Contributes to Protection of Intangible Cultural Heritage*
}

\author{
Rui Zhang \\ Department of Industrial Design \\ Hubei Institute of Fine Arts \\ Wuhan, China
}

\begin{abstract}
Intangible cultural heritages are mostly produced in the age of farming civilization and are products of regional economy. The current globalization has had a tremendous impact on the soil on which they survival and develop. How to protect, inherit and develop them has become a topic of widespread concern in recent years. The emergence of cultural creativity has provided a new way of thinking to resolve this stalemate.
\end{abstract}

Keywords-cultural creativity; design; intangible cultural heritage; gene

\section{INTRODUCTION}

The cultural characteristics of each country or region are derived from its localized life. However, the process of modernization is rapidly changing people's way of life. The old style of production and life led by regional economy has been greatly impacted in the process of global economic integration, and local culture is inevitably being influenced by more and more foreign culture.

\section{CUlTURAL CHARACTERISTICS BASED ON LOCALIZED TRADITIONAL LIFESTYLES}

Intangible cultural heritage, as a typical carrier of traditional lifestyles with cultural characteristics, is the product of historical and cultural accumulation, is formed through continuous accumulation in the development process, and has obvious regional characteristics. Taking China's intangible cultural heritage as an example, its manifestations are in full compliance with the characteristics of the regionalized economy in the agricultural era. It can completely match the local customs, folk customs, social structures, and economic development patterns at the historical nodes, and thus can completely assimilate into the local life. As time goes by, the cultural and ecological environment which the intangible cultural heritage relied on has changed, and people' s needs have also changed. Therefore, the protection and inheritance of intangible cultural heritage has naturally become a topic of widespread concern. Should we try our best to maintain the original state and the existing cultural and ecological

*Fund Project: General Project of Humanities and Social Sciences Research of Hubei Provincial Department of Education: "Promoting the Protection and Development of the Intangible Cultural Heritage in Hubei through Cultural and Creative Design" (Project ID: 16Y160). environment of these intangible cultural heritages [1]? Or should we view its development with the concept of living inheritance (or variability)? Or are there other better ways to help it continue to develop? There are different views and a lot of discussion over the topic. However, no intangible cultural heritage item is at its state of being initially created when it is identified as a list item. Based on this, it can be inferred that whether woodcarvings, New Year pictures or folk music, song and dance are constantly evolving and being perfected in their development processes, they are cultural creations in the course of evolution, so we must use the bidirectional thinking of inheritance and development to rationally look at this issue.

\section{Purposeful CUltural Production AND CONSUMPTION}

Compared with the intangible cultural heritage created during the historical process, the cultural and creative industries is said to be a purposeful cultural production and consumption. The former carries too much history and emotion, and is a manifestation of the local characteristics of the cultural producers. The latter is a new industry which emerges in the background of economic globalization and is guided by economic value and takes creativity as the core. Cultural concepts are transformed into commodities of economic value through innovative activities, originality and innovation are brought into production and service processes, thereby the value is created. This process of creating value differs from the process in which inheritors of intangible cultural heritage use their personal skills and talents to create value. The latter is a workshop-style, teacher-inheritance, small-scale and purely manual output, while cultural creativity industry reflects the characteristics of modern industrial production such as industrialization, mass production, and high added value, and is regarded as the globalization of cultural consumption.

Some people think that intangible cultural heritage, as the essence of culture, although exists in current society, it still belongs to the protected "cultural relics". Any alteration or change will damage the intangible cultural heritage. At the same time, there are also people who believe we should view the problem from the perspective of development and should not persist in the status quo. They think that treating and protecting intangible cultural heritage with a solidified method is the same as destroying them. In the "Convention on the 
Protection of Intangible Cultural Heritage", UNESCO has clearly stated that having the possibility of sustainable development is an important condition for applying for protection as the world's intangible cultural heritage, and the definition of "protection" is interpreted as: "Various measures to ensure the vitality of intangible cultural heritage". [2]

In his book, Mr. Fei Xiaotong mentioned that if a nation wants to maintain its characteristics in development, it must use its unique advantages to develop its economy. Otherwise, this nation will inevitably die or lose its original characteristics. [3] Therefore, in a sense, cultural and creative industry is one of the effective ways to help safeguard the intangible cultural heritage. It can stimulate the vitality of intangible cultural heritage with the market economy means and enable it to continuously innovate and develop in order to adapt to the new era.

\section{INHERITANCE AND INNOVATION OF CULTURAL GENES}

What the intangible cultural heritage expresses is the inheritance of traditional culture. It manifests as a stable inheritance relationship that takes place within the ethnic group. It is an academic concept in folklore. Compared with the inheritance and circulation of objects, intangible cultural heritage embodies a living culture full of vitality. Before it was defined as "intangible cultural heritage", it had also been updated and developed in order to adapt to the changes in social ecology. Therefore, in addition to protecting the identified items with the policy and statute, it is more important to view the items from the perspective of inheritance and innovation. If we are completely stuck to the old form, it will only make the protection a means to stop the change of traditional cultural expressions and to hold back its vitality.

Take folklore performance as an example. It originates from the lifestyles of the local residents. It is a kind of selfconscious and spontaneous behavior that reveals true emotions of residents in the process of production and in life. If this selfconscious behavior becomes a performance, the meaning of culture to life contained in the original behavior, the connotation behind the expression form, and the true emotions that people put into it will all disappear. Visible "shape" is preserved, but the invisible "quality" — the core of cultural spirit disappears. This is the true absence of cultural inheritance. [4]

Intangible cultural heritage is the essence of traditional culture. Its cultural value, artistic value and historical value are all very high. A certain number of intangible cultural heritage items (or their material carriers) have product attributes. They were bought and sold as commodities in the former social economic system, and were used as everyday utensils in life at that time. China has rich intangible cultural heritages and can provide sufficient cultural resources for the cultural and creative industries. The core of the cultural and creative industry is creativity, and creative design based on culture is an important embodiment of creativity. At this level, cultural and creative design can serve as a bearer of traditional cultural genes. Using design as a means and product as a carrier, combined with contemporary people's lifestyles and aesthetic interests, cultural genes can be injected into new products through design. We should promote the innovation of the culture to meet the characteristics of the current era and let the user engender cultural consciousness in the process of watching, feeling and using products.

\section{CONCLUSION}

How to better protect the intangible cultural heritage has always been the focus of various circles, and the debate that is detached from the subject often leads to the loss of the right to speak of the inheritors of intangible cultural heritage. A large number of external promoters are excessively involved in various ways, such as administrative thinking and marketbased capital operations. This makes the intangible cultural heritage passively withstand many of the protection activities, which is extremely unfavorable to the intangible cultural heritage itself. As for the status quo of the protection and development of intangible cultural heritage, due to the impact of social transformation, urbanization, and industrialization, the overall situation is not so optimistic as expected. The problems faced are complex, and new problems are constantly emerging. First, there are more people who are willing to learn intangible cultural heritage with commercial value, while there are few who want to learn intangible cultural heritage with no commercial value. Because there are differences between persons, even the works of the same intangible cultural heritage are slightly different from each other. It is impossible to make a standard to evaluate them. Second, since the intangible cultural heritage has actually distanced itself from the current lifestyle, it is impossible to require people to change their lifestyles to adapt to the old living style. Just as nowadays in the information society, people send information through the Internet, and it is impossible for people to write letters with a brush as before. Thirdly, intangible cultural heritage is a form of cultural expression that has been inherited and developed for thousands of years and cannot adapt to the modern intellectual property system. This has caused a problem that the intellectual property of the inheritor is not clear. Taking embroidery as an example, the used patterns and figures are not created by the inheritors. As the subject, the inheritor has a manual skill that is not easily imitated and copied by others. This is the reason why intangible cultural heritage cannot be seamlessly connected with the modern intellectual property system.

Feng Jicai, vice chairman of China Federation of Literary and Art Circles, recently mentioned that intangible cultural heritage is a living cultural heritage carried by human beings. It currently faces three problems: First, the inheritors are old and the inheritance cannot be ensured. Second, the environment is rapidly changing and the carrier is disintegrating. Third, life has changed and intangible cultural heritage is not needed by the next generation. [5] Each of the above-mentioned problems is straight to the point. In the absence of a practical solution at the moment, cultural and creative design is undoubtedly an effective tool to promote the protection of intangible cultural heritage. From a cultural perspective, a good design will reflect the spiritual core of culture. This is the genetically inherited refinement and recreation. In this sense, it is in line with the living inheritance of intangible cultural heritage. And compared to the fixed 
inheritance model, the creative design approach provides greater room for development and more possibilities. For intangible cultural heritage, it is also a spread in cultural space. From the economic perspective, cultural and creative design is in line with the market and gains value through application of cultural design. This avoids the negative influence of overmarketization on the ontology of intangible cultural heritage. The ontology can be inherited completely, and the design based on the ontology can be put into the market to generate economic benefits, and in turn, it can also help to increase the value of the ontology. From the perspective of people, the industrial chain will drive more people to participate in, such as inheritors, designers, manufacturers, media people, consumers, etc., to achieve a benign and orderly development. This is the true embodiment of the living heritage of intangible cultural heritage.

\section{REFERENCES}

[1] Zhang Bo: "Intangible cultural heritage cannot be innovated in general terms", “The Central Plains Culture Research", 2015, 4, pp. 106-109. 张 勃:”非物质文化遗产不能笼统谈创新”, 《中原文化研究》, 2015，4，第 106-109 页

[2] UNESCO: "Convention on the Protection of Intangible Cultural Heritage", "Communication of the Standing Committee of the National People's Congress of the People's Republic of China", 2006, 2, pp. 139. 联合国教科文组织: “保护非物质文化遗产保护公约”, 《中华人民 共和国全国人民代表大会常务委员会公报》，2006，2，第 139 页

[3] Fei Xiaotong: "Human Research in China", Tianjin People's Publishing House, Tianjin, 1993, pp. 372. 费孝通: 《人的研究在中国》, 天津 人民出版社, 天津, 1993 , 第 372 页

[4] Zhu Wei, "Intangible Cultural Heritage and Cultural and Creative Industries", “Cultural Heritage", 2015, 4, pp. 13-19. 朱伟: ”非物质文 化遗产与文化创意产业”， 《文化遗产》，2015，4，第 13-19页

[5] Feng Jicai: "There must be a cultural consciousness of protecting the intangibles", "People's Political Consultative Conference". 2015-11-23, Issue 03. 冯骥才: “要有保护非遗的文化自觉”，《人民政协 报》.2015-11-23 期 03 版

[6] Zhang Jingming: "Relations between protection strategies for fine arts intangible cultural heritage and cultural dressing industry in Northeast China”, Journal of Jiangnan University, 2013,12, pp. 108-114. 张景 明: “东北美术类非物质文化遗产保护对策与文化穿衣产业的关 系”, 《江南大学学报》，2013，12，第 108-114 页

[7] Guo Weiping : "The Explanation of Cultural Evolution Memes on Chinese Blessing Culture", Journal of Chongqing University of Technology, 2007, 21, pp. 130-140. . 郭卫平： "文化进化的模因论对 中华福文化的阐述”, 《重庆工学院学报》, 2007, 21, 第 130-140 页

[8] Liu Zhijun; "Anthropological perspective on the protection of intangible cultural heritage", Journal of Zhejiang University (Humanities and Social Science Edition), 2009, 7, pp 26-35. 刘志军; “非物质文化遗产 保护的人类学透视”, 《浙江大学学报》(人文社会科学版), 2009,7，第 26-35 页

[9] Zheng Xin, "Discussion On the Interrelationship between China's Cultural and Creative Industries and Intangible Cultural Heritage", Journal of Qiqihar University (Philosophy and Social Science Edition), 2012, 4, pp.141-143. 郑金: “论中国文化创意产业与 “非物质文化遗 产, 间的互摄关系”, 《齐齐哈尔大学学报》（哲学社会科学 版），2012,4，第 141-143 页

[10] Liu Yu, Zhang Limin, "Reflections on Intangible Cultural Heritage as a Home Gene of the Cultural and Creative Industries", Shandong Social Sciences, 2012, 11, pp. 94-97. 刘宇、张立敏: “非物质文化遗产作为 文化创意产业本位基因的思考”, 《山东社会科学》, 2012,11, 第 94-97 页 